\title{
Properties and Applications of Bamboo Fiber-A Current-State-of-the Art
}

\section{Chen Chen ${ }^{1,2}$, Haitao Li $^{1,2, *}$, Assima Dauletbek ${ }^{1,2}$, Feng Shen ${ }^{3}$, David Hui ${ }^{4}$, Milan Gaff ${ }^{5}$, Rodolfo Lorenzo $^{6}$, Ileana Corbi ${ }^{7}$, Ottavia Corbi ${ }^{7}$ and Mahmud Ashraf ${ }^{8}$}

${ }^{1}$ College of Civil Engineering, Nanjing Forestry University, Nanjing, 210037, China

${ }^{2}$ Joint International Research Laboratory for Bio-Composite Building Materials and Structures, Nanjing Forestry University, Nanjing, 210037, China

${ }^{3}$ Jiangsu Fiber Composite Co., Ltd., Yancheng, 224700, China

${ }^{4}$ Department of Mechanical Engineering, University of New Orleans, Los Angeles, 70148, USA

${ }^{5}$ Department of Wood Processing, Faculty of Forestry and Wood Sciences, Czech University of Life Sciences Prague, Suchdol, 16521, Czech Republic

${ }^{6}$ University College London, London, WC1E 6BT, UK

${ }^{7}$ University of Naples Federico II, Naples, 80133, Italy

${ }^{8}$ Deakin University, Geelong, Waurn Ponds, VIC 3216, Australia

*Corresponding Author: Haitao Li. Email: lhaitao1982@126.com

Received: 10 August 2021 Accepted: 19 August 2021

\begin{abstract}
Fibers are used in many forms in engineering applications-one of the most common being used as reinforcement. Due to its renewable short natural growth cycle and abundance of bamboo resources, bamboo fiber has attracted attention over other natural fibers. Bamboo fiber has a complex natural structure but offers excellent mechanical properties, which are utilized in the textile, papermaking, construction, and composites industry. However, bamboo fibers can easily absorb moisture and are prone to corrosion limiting their use in engineering applications. Therefore, a better understanding of bamboo fiber is particularly important. This paper reviews all existing research on the mechanical characterization of bamboo fiber with an emphasis on the extraction and treatment techniques, and their effect on relevant properties. The chemical composition of bamboo fibers has also been thoroughly investigated and presented herein. Current applications and future opportunities for bamboo fibers in various fields have been presented with a focus on research needs. This work can serve as a reference for future research on bamboo fiber.
\end{abstract}

\section{KEYWORDS}

Bamboo fiber; chemical composition; structure; production method; properties; application

\section{Introduction}

Bamboo is a naturally grown renewable material that will decompose if discarded after end-of-life, and it offers excellent environmental performance based on the Life Cycle Assessment (LCA) [1]. The use of bamboo in construction is in line with the concept of sustainable development [2-9].

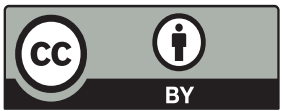

This work is licensed under a Creative Commons Attribution 4.0 International License, which permits unrestricted use, distribution, and reproduction in any medium, provided the original work is properly cited. 
In view of sustainability, the development and utilization of natural fiber [10-12] have become a research hotspot. Bamboo fiber can be directly extracted from bamboo to be used for other engineering applications. The cross-section of bamboo fiber presents a hollow structure offering excellent moisture absorption ability and air permeability; and the vascular bundles of bamboo fibers are distributed along the radial direction, which is conducive to the classification and utilization of bamboo fibers [13-17]. This paper reviews all research relevant to mechanical properties and utilization of bamboo fiber so that researchers are aware of the current-state-of-the-art to drive future innovation in this field.

\section{Classification of Bamboo Fiber}

Bamboo fiber (Fig. 1 [18]) can be divided into the natural bamboo fiber, bamboo pulp fiber, and bamboo charcoal fiber [19]. Natural bamboo fiber [20] is a fiber directly extracted from bamboo using physical or microbial degumming. The crystalline structure properties of the original bamboo fiber do not change during the extraction process, which makes the fiber natural. Bamboo pulp fiber [19] is made from bamboo pulp, suitable for the production of fiber, from which the fiber is then obtained. Bamboo charcoal fiber [20] is made by surface treatment of nano-level bamboo charcoal powder, then a slurry is added to the viscose and drawn into a wire shape; this method is mostly adopted in the textile industry.

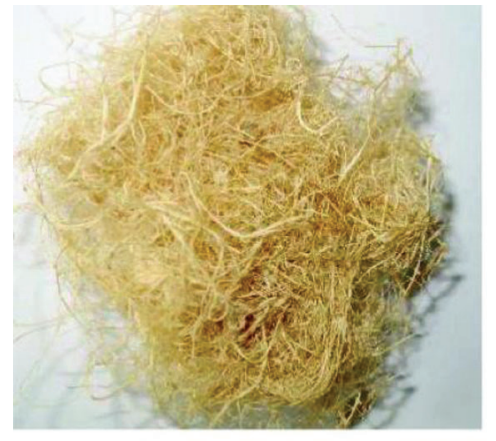

(a)

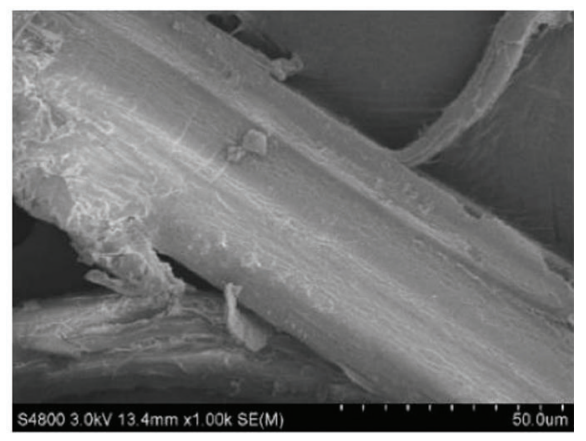

(b)

Figure 1: Bamboo fiber: (a) Macroscopic bamboo fiber, (b) Scanning electron microscopic image [18]

In China, bamboo fiber is mainly divided into the aforementioned three categories. Natural bamboo fiber retains the characteristics of the original bamboo but this requires more raw materials making the manufacturing process of natural fibers technically inefficient. At present, bamboo fiber products on the market are mainly made of bamboo pulp fiber and bamboo charcoal fiber [13].

\section{The Chemical Composition of Bamboo Fiber}

Bamboo fiber is a natural bio-composite and the main chemical constituents of bamboo fiber are cellulose, hemicellulose, and lignin [19,21].

\subsection{Cellulose}

Cellulose [22] is mainly composed of three elements such as carbon, hydrogen, and oxygen, and it is the material basis that forms the cell wall of bamboo fiber [19]. Typically, cellulose remains in the form of microfibrils within the cell wall of plant [23]. Wang et al. [24] analyzed the chemical composition of bamboo fiber used for textile after separation and found that its cellulose content reached $73.83 \%$. Cellulose is the main factor affecting the tensile strength along the grain of bamboo fiber and the cellulose content is closely related to the bamboo age. It is worth noting that the cellulose content of the same bamboo material decreases with the increasing age of bamboo [19]. 


\subsection{Hemicellulose}

Hemicellulose [19] is an amorphous substance offering a low degree of polymerization and it exists between fibers. Hemicellulose is a complex polysaccharide with xylan as the predominant chain, and the branches mainly include 4-O-methyl-D-glucuronic acid, L-arabinose, and D-xylose [25]. Fengel et al. [26] studied the polysaccharide fraction of Phyllostachys makinoi extracted with $5 \%$ and $17.5 \% \mathrm{NaOH}$ and observed that its main component was arabinoxylan, and the ratio of xylose to arabinose was 17-18:1. Sun et al. [27] analyzed the bamboo polysaccharide components extracted by two different methods and reported that most of the polysaccharide components after extraction with distilled water were glucose, while the content of xylose was higher after extraction with alkaline.

\subsection{Lignin}

Lignin [19] is a kind of polymer with complex structures and of many types. The basic units of lignin mainly include guaiacyl, syringyl monomers, and p-hydroxyphenyl monomers [25]. The structural units in lignin are mainly connected by ether bonds and carbon-carbon single bonds [19]. Lignin is not evenly distributed in the bamboo fiber secondary wall. Generally, the concentration of lignin in the broad layer is lower, while the concentration of lignin in the narrow layer is higher [25]. The presence of lignin also gives bamboo material a certain degree of stability. The lignin content also varies with the age of the bamboo [19]. The basic skeleton of lignin can be roughly divided into three types as shown in Fig. 2 [25].
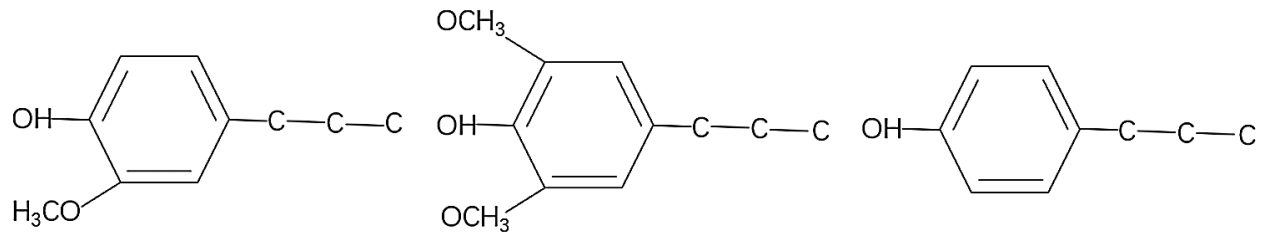

Figure 2: The basic skeletons of several lignins [25]

In addition to the three main components, lignin often contains various sugars, fats, and protein substances and a small amount of ash elements [19,21,25]. These chemical compositions affect not only the properties of bamboo, but also the application of bamboo fiber.

\section{The Basic Structure of the Bamboo Fiber}

The cells of bamboo are mainly composed of fiber cells, parenchyma cells, ducts, epidermal cells, sieve tubes, companion cells, and some other cells [25]. The cell structure is shown in Fig. 3 [28,29].

According to previous studies [19,25,28,29], bamboo fiber cells have no inner wall, but the middle layer of the secondary wall has a multi-layer structure. The orientation of microfibers varies between layers of the bamboo fiber cell wall, as well as between different types of bamboo. The direction of microfibers in the narrow layer is a near-horizontal spiral arrangement, whilst the direction of microfibers in the wide layer is a near-axial spiral arrangement. Due to the different fiber orientations of the narrow layer and the wide layer, bamboo is anisotropic. The different distribution of vascular bundles leads to different longitudinal permeability of bamboo fibers, which in turn affects the penetration of chemical reagents and has a certain impact on the composition analysis and production of bamboo fibers.

\section{Characteristics of Bamboo Fiber}

Considerable research has been reported on the characteristics of bamboo fiber highlighting its short production cycle and its environmental benefits compared to other artificial fibers. There are large voids between bamboo fibers, which can absorb various odors, dust, and other harmful substances, and can also purify the air and control humidity. The bamboo fiber has a strong antibacterial effect and contains 
sodium copper chlorophyll, which provides refreshing and anti-ultraviolet effect [19,30,31]. However, bamboo fiber also has some shortcomings including high water absorption, corrosion, and poor durability [19]. Hence, when using bamboo fibers, attention should be paid to water-proof and mildew-proof treatment to improve the durability of bamboo fiber products.

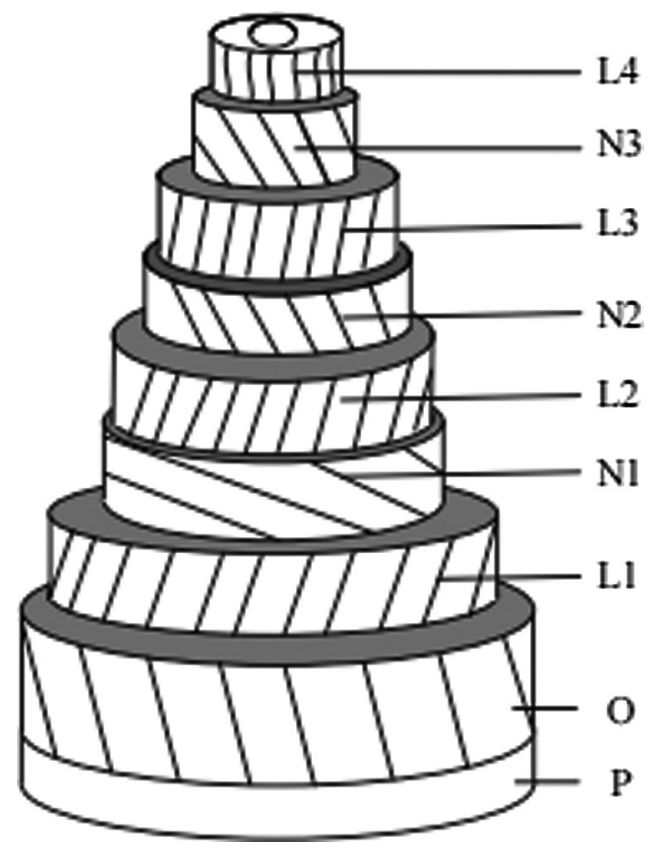

Figure 3: The model of polylamellae structure: the wide layer (L1-L4), the narrow layer (N1-N4), the primary wall $(\mathrm{P})$, the external sheet of the secondary wall $(\mathrm{O})[28,29]$

\section{Production Method of Bamboo Fiber}

According to the analysis, the microstructure of bamboo is anisotropic, which reduces the energy requirement to separate and extract bamboo fibers [19,25,32,33]. However, difficult aspects of the bamboo fiber production process are the removal of chemical components such as lignin and the decomposition of bamboo fiber. At present, methods of chemical, biological, physical, and joint production methods are commonly used [19]. $\mathrm{NaOH}$ can be used for the treatment of bamboo fibers [34-37]. However, increasing the concentration of $\mathrm{NaOH}$ adversely affects the tensile strength and tensile modulus of bamboo fibers; the addition of $\mathrm{NaOH}$ changes their brittleness to ductility [34]. Fig. 4 shows the scanning electron micrograph (SEM) of treated bamboo fiber [35].
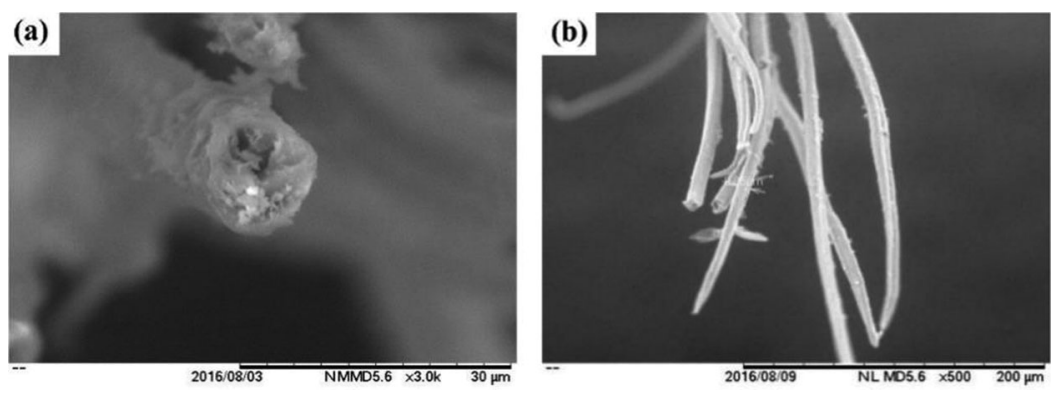

Figure 4: SEM images of bamboo fiber: (a) cross-section of bamboo fiber (b) longitudinal section of bamboo fiber [35] 
Extraction of bamboo fiber often requires a combination of methods to meet the application requirements. An et al. [38] developed a green integrated technology that combines ultrasonication with subsequent cellulase treatment. The ultrasonication destroyed the crystalline structure of the fiber and exposed its surface, which significantly improved the efficiency of cellulase treatment and improved the flexibility of the fiber. Fig. 5 is a schematic diagram of this method [38].

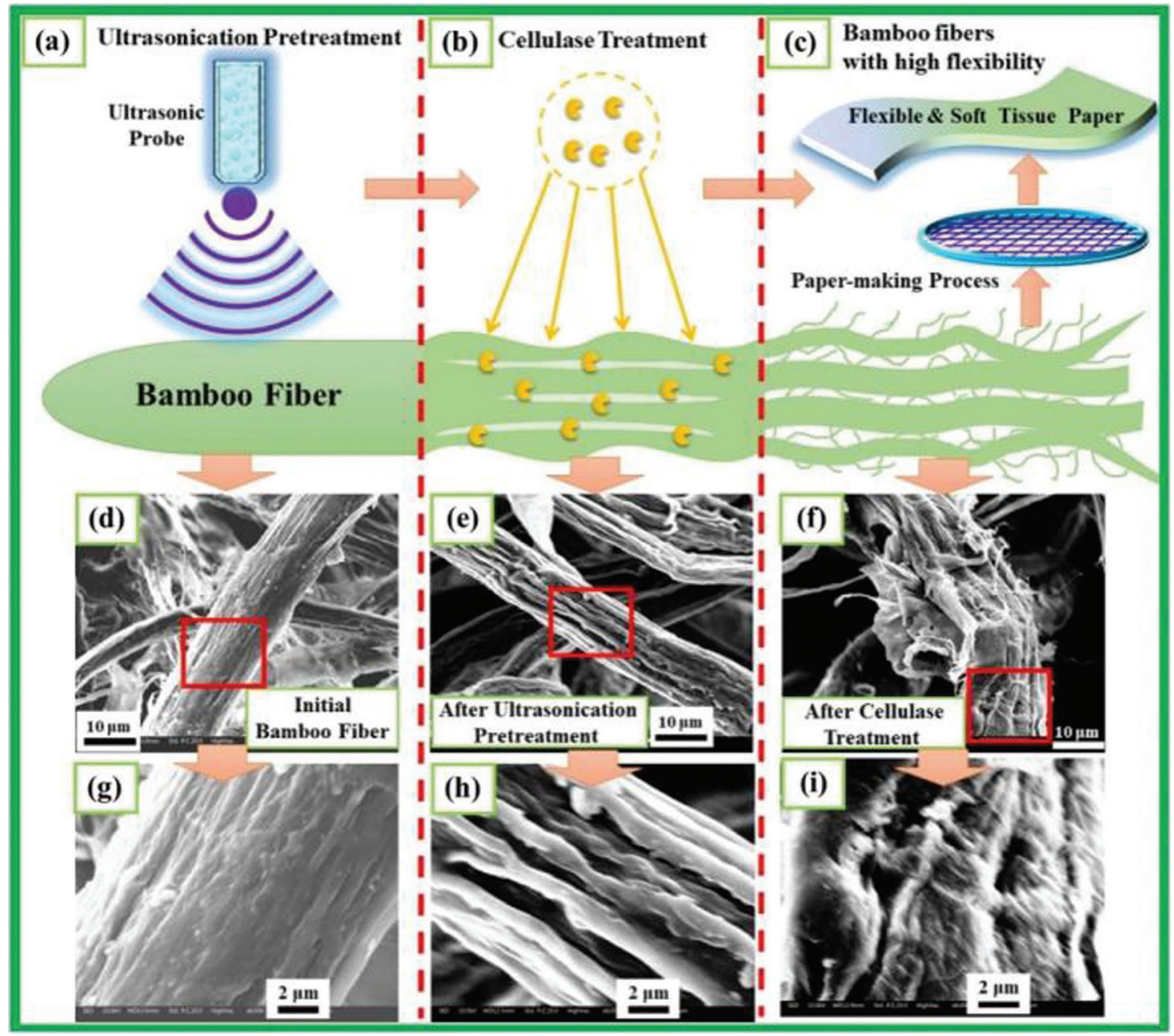

Figure 5: Schematic of ultrasonication pretreatment combined with cellulase treatment of bamboo CTMP fibers: (a) schematic of ultrasonication; (b) schematic of cellulase treatment effect; (c) schematic of bamboo fiber and preparation of soft tissue paper via a paper-making process; (d) SEM image of initial bamboo fiber; (e) SEM image of ultrasonication pretreated fiber; (f) SEM image of the bamboo fiber after ultrasonication and cellulase treatment (g) SEM image marked in (d); (h) SEM image marked in (e); (i) SEM image marked in (f) [38]

\section{Mechanical Properties of Bamboo Fiber}

\subsection{Testing Technology of Mechanical Properties}

Tensile testing of single fiber [39-41] refers to the direct axial stretching of tracheids or fibers at the single-cell level. Nanoindentation [41-43] consists of pressing a tiny diamond probe into the surface of the material with a very small force, and continuously collecting the load acting on the needle tip and the 
indentation depth of the sample during the loading and unloading process. Tensile testing of single fiber and nanoindentation are two commonly used technologies to measure the mechanical properties of plant cell walls.

Considerable research has been reported on the mechanical properties of bamboo fiber and the Young's modulus and the tensile strength were reported to be 11-17 GPa and 140-230 MPa, respectively [44]. Tan et al. [45] carried out a bamboo fiber cell wall indentation test and reported that the tensile modulus showed a decreasing trend from the outside surface of the bamboo to the inside surface. Wang et al. [46] compared the tensile mechanical properties of four different types of fibers: bamboo, kenaf, Chinese fir, and ramie, and the results showed that the tensile properties of the bamboo fiber were superior to the other fibers. Wang et al. [47] compared bamboo and wood fiber cell walls and observed that the mechanical properties of bamboo outperformed those of wood. Wang et al. [48] also reported that the orientation of cellulose fibrils was almost along the fiber axis to maximize the longitudinal modulus of elasticity. Rao et al. [49] compared chemically and mechanically extracted bamboo fibers; the mechanical properties of the chemically extracted fiber were superior to the mechanically extracted ones. Wang et al. [50] found that the fracture behavior of bamboo fibers that are adjacent to the inner part was brittle (Fig. 6a), whilst those closer to the outer part exhibited ductile fracture (Fig. 61).

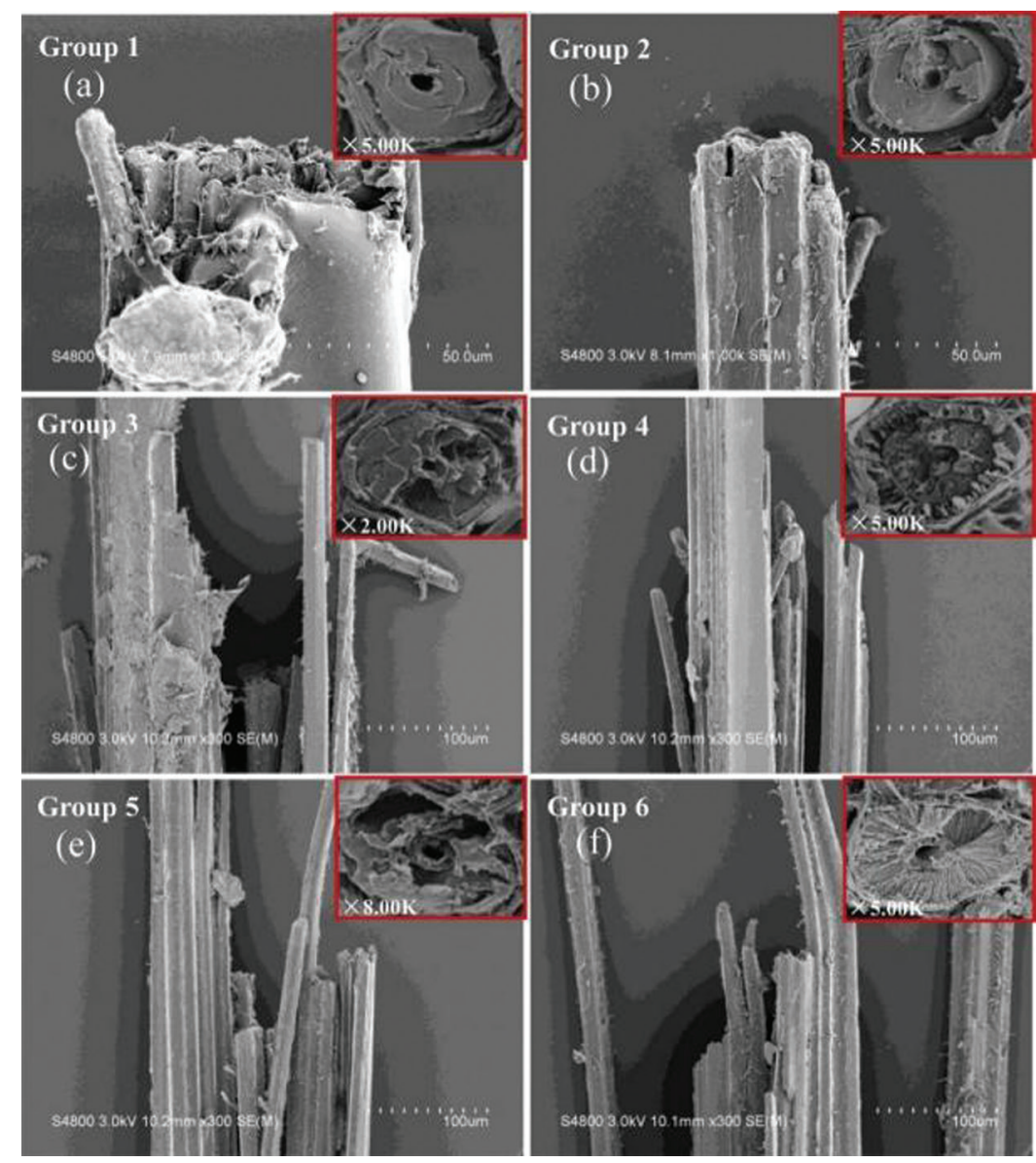

Figure 6: The SEM images of the fracture surface: (a)-(f): 6 groups of specimen samples from the inside to outside of the bamboo stem along the radial direction [50] 


\subsection{Influencing Factors of Mechanical Properties}

Many factors affect the mechanical properties of bamboo fibers such as the chemical composition and structure of bamboo fibers, moisture content, age of bamboo, etc. [41]. Tian [41] reported that the tensile modulus of bamboo decreased with the removal of hemicellulose but did not change significantly with the removal of lignin. The tensile strength of bamboo fiber also decreased with the removal of chemical constituents, whilst ductility decreased slightly with the removal of lignin but increased with the removal of hemicellulose.

The structure of bamboo fiber cells is complex, and the middle layer of the secondary wall of the cell has a multi-layered structure [19,28,29]. Therefore, the lignification of the thin and thick layers in the multilayer structure varies, and the orientation of the microfibrils is different, resulting in a relatively large difference in mechanical properties between adjacent wall layers [51,52]. The multilayered cell wall structure leads to better fracture resistance and promotes internal sliding between the cell wall layers during tension (Fig. 7) [53]. The microfibril angle is also an important factor affecting the mechanical properties of the fiber; typically, the tensile strength and tensile modulus of the fiber increase with decreasing microfibril angle [54-56]. Hence, the smaller microfibril angle is an important factor that contributes to the excellent mechanical properties of bamboo fiber.
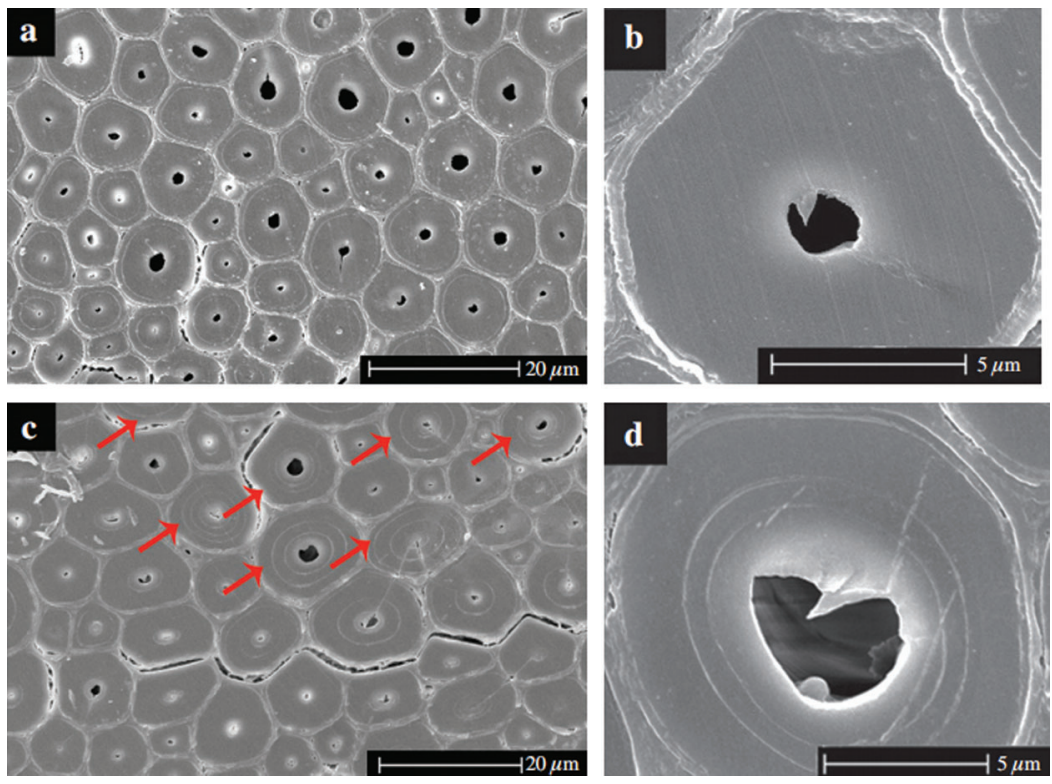

Figure 7: SEM images of bamboo fiber: a and b. one-year-old bamboo fiber, $\mathrm{c}$ and d. four-year-old bamboo fiber, the red arrows point to the fibers with more cell layers [53]

There are large voids between bamboo fiber molecules, which have good hygroscopicity. Therefore, the moisture content is also an important factor affecting the mechanical properties of bamboo fibers. Wang et al. [57] studied the effect of moisture content on the mechanical properties of bamboo from the macroscopic and cell wall scales, and reported that under the fiber saturation point, the compressive modulus of elasticity, the indentation modulus of elasticity, and hardness of bamboo fiber decreased with the increase in moisture content. Tian [41] used tensile test of single fiber and nanoindentation to study the effect of changes in moisture content on the mechanical properties of bamboo fibers and observed that as the moisture content increased, the tensile modulus and tensile strength of bamboo fibers decreased significantly but the elongation at break increased. Test results showed that the strength and stiffness of four-year-old fiber 
were better than those of one-year-old fiber, but the difference in the mechanical properties of the single fiber in the longitudinal and radial directions of the bamboo stalk was not obvious [43].

Previous research projects on bamboo fibers primarily focused on the mechanical properties and relevant factors affecting those properties by using tensile test and nanoindentation techniques. Reported research outcomes clearly show that bamboo fibers offer excellent mechanical properties. Additional research is required for the general characterization of bamboo fibers and their extraction methods to promote their use in various engineering and everyday product applications.

\section{Application of Bamboo Fiber}

Bamboo fiber is currently used in the textile, papermaking, and construction industries in various formats. Recently, bamboo fiber has attracted the attention of composite material researchers and has been gradually making its way into the composite material industry.

\subsection{Textile Industry}

Compared to other fibers, bamboo fiber has good hygroscopicity, can reflect light, and reduce the absorption of heat radiation, and can be used for clothing production [58,59]. At the same time, bamboo fiber has a strong antibacterial effect and can be used in the production of medical supplies, such as masks and medical gauze [19]. In the textile industry, bamboo fiber can be utilized on its own or in combination with other materials such as silk and cotton fibers.

Despite the potential and widespread application of bamboo fiber in the textile industry, some of its shortcomings, such as the short length of single bamboo fiber and the easy water absorption of bamboo fiber fabrics should be addressed through fundamental research.

\subsection{Papermaking Industry}

Since bamboo fiber has an antibacterial effect and its length is close to coniferous trees, it can be used in the papermaking industry [60-64]. China has a long history of using bamboo for papermaking. Bamboo was utilized in the papermaking industry as early as 1700 years ago. And the use of bamboo for machine-made paper production in China began in the 1940s [63]. In recent years, due to the shortage of wood fiber, bamboo fiber has become an indispensable raw material for papermaking [61]. It should be noted that although bamboo fiber is a good papermaking material, compared to wood, the cost of bamboo planting, storage, and transportation is higher, and the price of bamboo fiber is easily affected by the market [61].

\subsection{Construction Industry}

Studies have shown that in the production of some building materials, natural fibers can replace traditional steel [65] and synthetic fibers [66], and improve their mechanical properties [67-69]. Bamboo fiber is a natural fiber with excellent mechanical properties, and incorporating it into concrete leads to better physical and mechanical properties [70,71]. Terai et al. [72] studied the effect of adding $0 \%, 1 \%$, and $2 \%$ (by volume) bamboo fiber on the mechanical properties of concrete and found that the flexural strength, tensile strength, and compressive strength of bamboo fiber reinforced concrete increased with the increase in bamboo fiber content. Wahyuni et al. [73] added $0.50 \%$ bamboo fiber based on the weight of cement and compared splitting tensile strength of concrete at the age of 28 and 90 days; test results showed that the mechanical properties of the new type of concrete mix were comparable to those of ordinary concrete. Ramaswamy et al. [74] studied the deformation properties of bamboo fiber concrete and reported that the addition of bamboo fiber could reduce the shrinkage deformation of coagulation. Chin et al. [75] conducted experiments on bamboo fiber composite plate (BFCP) reinforced concrete beams, and the results showed that its structural bearing capacity increased by $10-12 \%$ compared to unreinforced beams. 
Bamboo fiber can also be added to the cement paste to develop bamboo fiber reinforced cement [76]. Studies have shown that adding an appropriate amount of bamboo fiber can enhance the toughness of cement, but if the amount of bamboo fiber is excessive, it can cause fiber agglomeration (Fig. 8) and, hence, cannot enhance the maximum flexural strength and impact resistance of the composites [77]. Akinyemi et al. [78] studied the effects of different pre-treatment methods on bamboo fiber cement composite materials and observed that microwave-assisted alkali treatment enhanced mechanical properties. Sanchez-Echeverri et al. [79] compared the performance of bamboo fiber reinforced cement made from treated and untreated bamboo fibers and reported that the applied alkali treatment produced enhanced flexural strength. They also observed that after alkali treatment, the impurities on the surface of the bamboo fiber were significantly reduced giving a cleaner surface (Fig. 9) [79]. Huang et al. [80] analyzed the applicability of bamboo fiber and bamboo charcoal resources as building fillers in tropical and subtropical regions through the hygrothermal properties test as well as through simulation of the building component and the enclosed space.
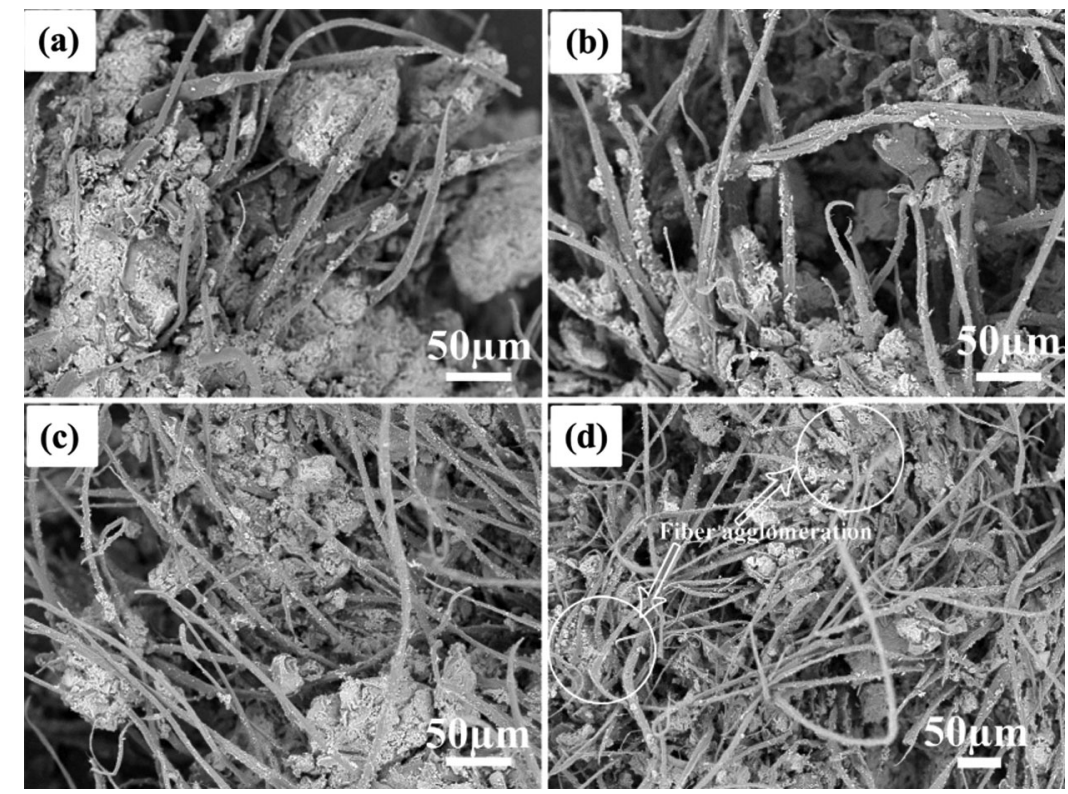

Figure 8: SEM images of fracture surface: (a) 4\% (by weight) bamboo fiber, (b) $8 \%$ (by weight) bamboo fiber, (c) 12\% (by weight) bamboo fiber, (d) 16\% (by weight) bamboo fiber [77]

\subsection{Composite Material Industries}

Due to the advantages of bamboo fiber composite materials such as low density, light weight, and good extensibility, they have the potential to be used in aerospace, marine engineering, advanced rail transit, power equipment, and automobile manufacturing, etc. [19]. In daily life, similar to wood [81], bamboo fiber composite materials can be used to make furniture, flooring, and sports equipment such as decks [82]. Test evidence reported on bamboo fiber reinforced composites are quite promising although the manufacturing technique of such composites would require significant research.

The bamboo fiber secondary wall contains alternating broad and thin layers with a distinct transition zone between the layers. Li et al. [83] were inspired by the transition zone in the bamboo fiber secondary wall and designed a similar zone in the glass fiber/epoxy and glass fiber/polyester composites. The test results showed that the interlaminar shear strength of the glass fiber/epoxy and glass fiber/polyester composites with transition zone about $15.8 \%$ and $13.3 \%$ higher than those without transition zone for the 
considered composites respectively. Mandal et al. [84] studied the properties of glass/bamboo fiber reinforced unsaturated polyester resin-based hybrid composites made by replacing $25 \%, 50 \%$, and $75 \%$ (by weight) of glass fibers with bamboo fibers. Test results showed that whilst the addition of $25 \%$ bamboo fiber did not cause fiber aggregation and had little effect on the performance of composites, the addition of excessive bamboo fibers caused the fiber/matrix segregation leading to inferior performance. Samal et al. [85] studied the influence of the content of maleic anhydride grafted polypropylene (MAPP) on the mechanical properties of polypropylene-bamboo/glass fiber hybrid composites. It was reported that MAPP improved the interface interaction between the fiber and the matrix and enhanced the mechanical properties of the composite such as the tensile strength, tensile modulus, flexural strength, flexural modulus, and impact strength. Rao et al. [86] studied the bending and compression properties of bamboo/glass fiber reinforced epoxy hybrid composites. The test results showed that the bending and compression properties of composite materials increased with the increase in glass fiber content, and the performance of composites made from bamboo fiber treated with alkali was better.
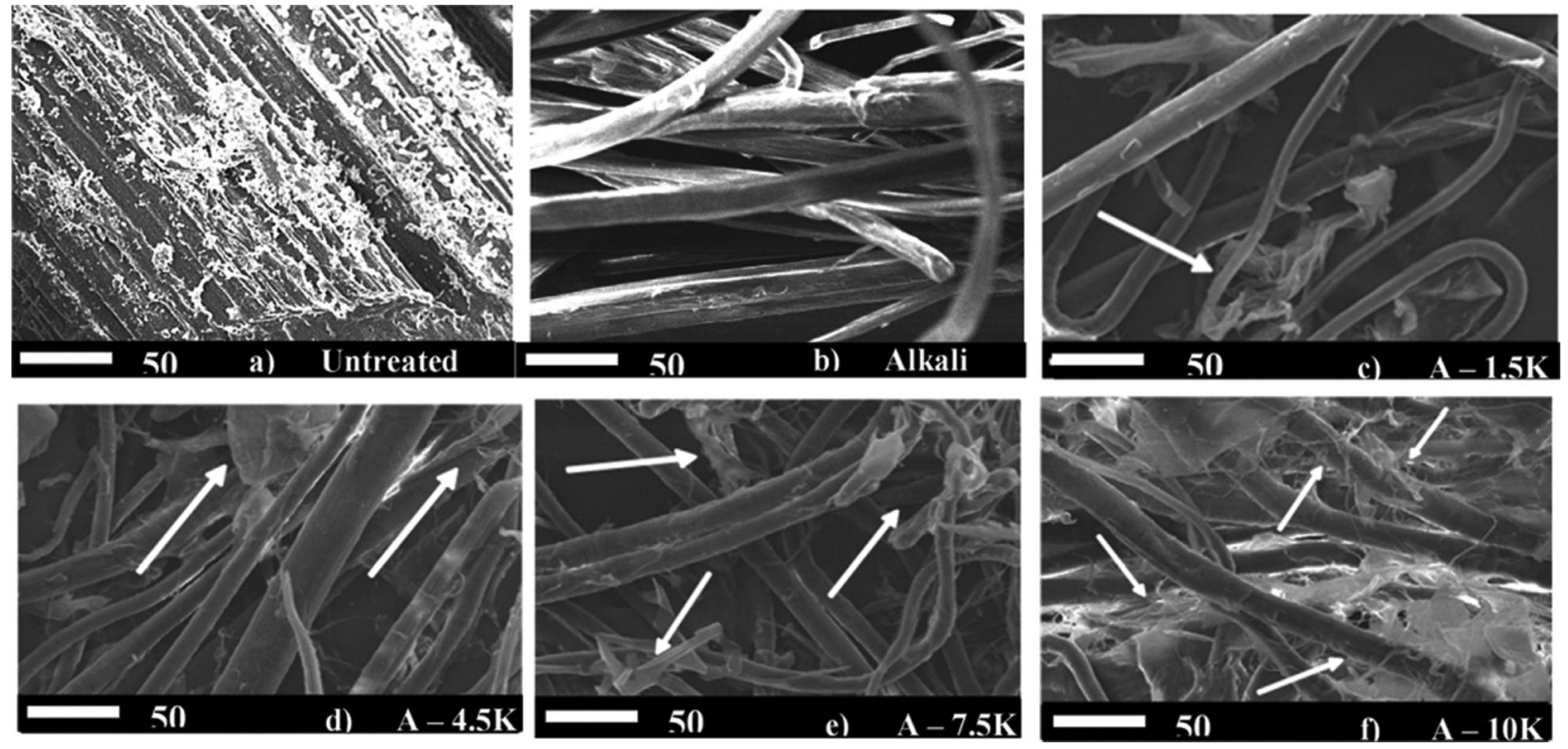

Figure 9: SEM images of fibers before and after the treatment. The fibers were refined with different degrees of beating: (a) 0 , (b) 1,500, (c) 4,500, (d) 7,500, and (e) 10,000 revolutions. The white arrows indicate fibrosis due to the refining process [79]

Studies have shown that the use of natural fibers such as bamboo fiber can enhance the toughness of brittle thermosetting polymers such as polyester and epoxy [87-90]. Bamboo fibers can be mixed with various polymers to form new materials, such as polyester-based bamboo fiber reinforced composites, epoxy-based bamboo fiber reinforced composites, phenolic resin-based bamboo fiber reinforced composites, polypropylene-based bamboo fiber reinforced composites, polyvinyl chloride-based bamboo fiber reinforced composites, and polystyrene-based bamboo fiber reinforced composites [82].

Nguyen et al. [91] studied bamboo fiberboard made of bamboo fiber and protein-based bone glues and observed that the pores of the fiberboard were relatively large, and the best pressing conditions for bamboo fiberboard were at $150 \mathrm{kgf} / \mathrm{cm}^{2}$, with the temperature of $160^{\circ} \mathrm{C}$, and the pressing time of $15 \mathrm{~min}$. Chin et al. [35] carried out tensile and flexural tests and reported that bamboo fiber reinforced epoxy composites (BFREC) with a fiber volume fraction of $40 \%$ had higher tensile and flexural strength ratios than bamboo 
fiber reinforced polyester composites (BFRPC) and bamboo fiber reinforced vinyl ester composite (BFRVC); the reported comparison is shown in Fig. 10 [35]. Kumari et al. [92] used natural bamboo fiber (BF), polyester resin (PR), and Euphorbia cementitious (EC) as raw materials to prepare new composite material that could be used for wood substitutes, automobile parts, sports equipment, etc.

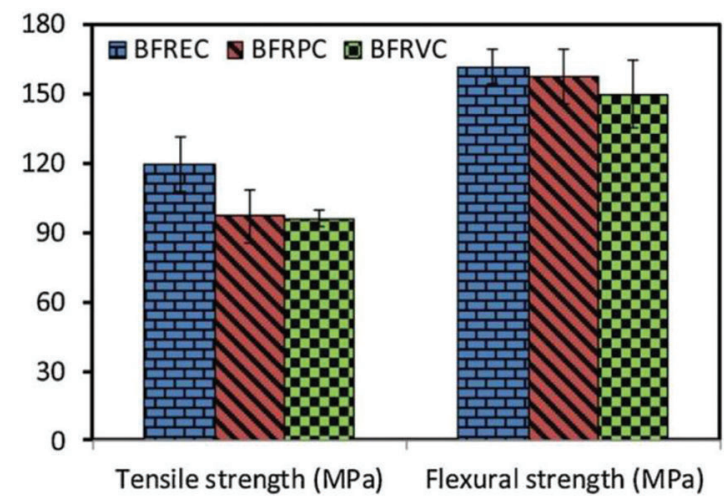

Figure 10: The comparison of tensile and flexural properties of bamboo fiber composites [35]

Chen et al. [93] studied the effect of the amount of MAPP on the properties of bamboo fiber reinforced polypropylene composites (PP) and observed that when the amount of MAPP was $24 \%$ by weight, the tensile modulus, tensile strength, impact strength were significantly improved. Phuong et al. [94] studied the effect of chemical treatment of bamboo fibers on the properties of recycled polypropylene/bamboo fiber composites and reported that alkali treatment removed impurities on the surface of bamboo fibers, increased the contact surface of bamboo fiber within composites, and improved the tensile strength and Charpy impact strength of the composite material.

Lee et al. [95] studied the effects of chemical modification (silane coupling) and filler loading on the properties of bamboo fiber-filled polypropylene bio-composites. Test results showed that as bamboo fiber loading increased, the tensile strength, flexural strength, and impact strength of the material decreased, while the tensile modulus, flexural modulus, and water absorption of the material increased. Tang et al. [96] prepared polypropylene-based composites reinforced with single bamboo fibers and analyzed the effect of single bamboo fiber content on the properties of the material. It was observed that the impact strength and the elastic modulus increased with the increase in the single bamboo fiber content, which enhanced the toughness and rigidity of the composite.

Bamboo fiber reinforced epoxy composites have also attracted attention in the recent past. Lokesh et al. [97] studied the effect of bamboo fiber content on the mechanical properties of bamboo fiber-reinforced epoxy composites; test results showed that the impact strength, tensile strength, and flexural strength of composites increased with the increase in fiber content, but excessive bamboo fiber caused the lack of proper bonding between the matrix and the fibers around the interface, resulting in poor mechanical properties of the composite material. Nirmal et al. [98] used different fiber orientations in the epoxy matrix as influencing factors to explore the adhesive wear and friction properties of bamboo fiber reinforced epoxy composites. Based on the test evidence they reported that the composites showed excellent adhesive wear when the bamboo fibers were not parallel to each other. Alkali treatment has been reported to enhance the performance of bamboo fiber reinforced epoxy composites [99-101]. In addition to alkali treatment, Kushwaha et al. [99] also studied the effects of treatments with different silane derivatives on the water absorption properties of bamboo fiber reinforced epoxy composites and found that the effect of treating with Aminopropyltriethoxysilane produced the best outcome. 
Huang et al. [100] studied the effect of bamboo fiber diameter on the tensile properties of bamboo fiber reinforced epoxy composites; conducted tests showed that the tensile strength and Young's modulus of the composite increased as the diameter of the bamboo fiber decreased. Rajulu et al. [102] produced short bamboo fiber reinforced epoxy composites, and reported that with the increase in bamboo fiber content, the void content and density of the material showed a decreasing trend.

Tang et al. [103] improved the mechanical properties of phenolic foams by adding bamboo fiber and concluded that phenolic foam composites achieved the best mechanical properties when bamboo fiber was added $2.5 \%$ (by weight). At the same time, by observing the microscopic image of the composites (Fig. 11), it was concluded that the fiber was well impregnated in the foam cell and did not pass through the cell. Das et al. [104] studied the fracture energy of unidirectional bamboo strips-novolac composites, and the test results showed that the long fibers in the composite material made of bamboo treated by $\mathrm{NaOH}$ were pulled out, which led to an increase in the fracture energy of composites.
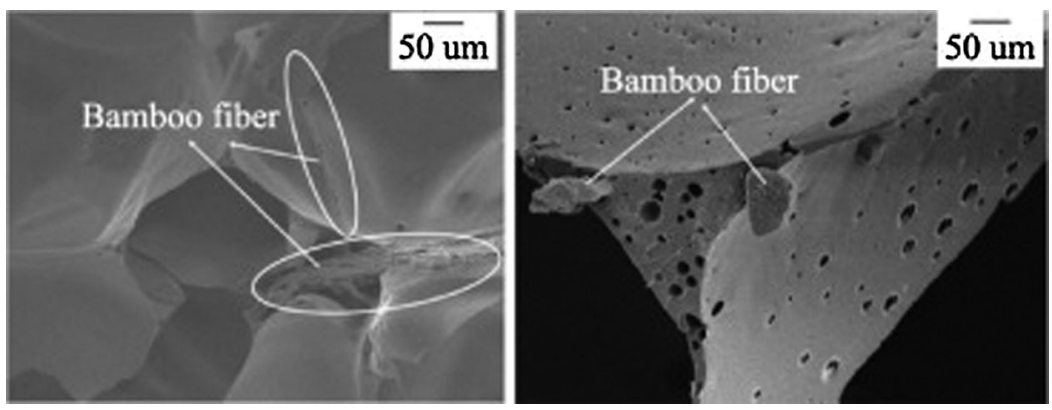

Figure 11: The microscopic image of phenolic foam composites [103]

Yusof et al. [105] compared the mechanical properties of bamboo fiber reinforced tapioca starch biodegradable composites made from untreated, alkali-treated, and permanganate-treated bamboo fibers. The test results showed that the tensile strength, tensile modulus, flexural strength, and flexural modulus of the treated composites were higher than those of the untreated composites, and the mechanical properties of the alkali-treated composites were the best.

Jena [106] studied the effects of two short bamboo weight fractions, i.e., $10 \%$ and $15 \%$ by wt., on the mechanical properties of short bamboo fiber reinforced polyester composite beams; test results showed that $15 \%$ by wt. produced higher hardness, tensile strength, and impact strength but $10 \%$ by wt. fraction produced higher flexural strength.

Rawi et al. [107] measured the impact strength of bamboo fabric-poly (lactic acid) composites. The test results showed that compared with pure polylactic acid, the impact strength (warp direction) of bamboo fabric-poly(lactic acid) composites increased by $240 \%$. It should be noted that bamboo fabric-poly (lactic acid) composite, as an environmentally friendly material, has a wide range of application prospects [108]. Porras et al. [109] studied the performance of Polylactide/Bamboo fabric composites. They used the scanning electron microscope to observe the bond between the bamboo fiber and polylactide matrix, and reported that bamboo fibers were well dispersed in composites and could also pass through the matrix producing a better combination (Fig. 12). They also observed the tensile failure morphology of the bamboo fabric/PLA laminate and reported that the matrix failure was characterized by brittle behavior in a staggered manner (Fig. 13). 


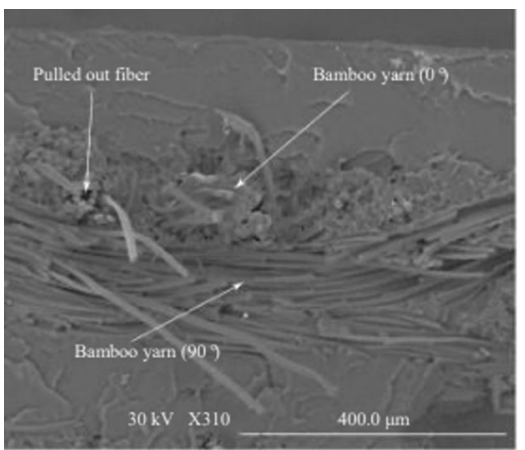

(a)

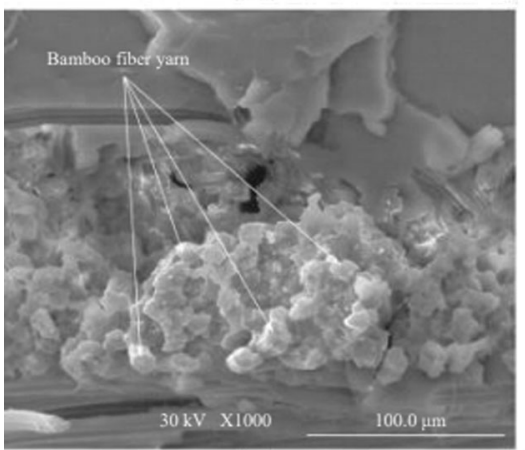

(c)

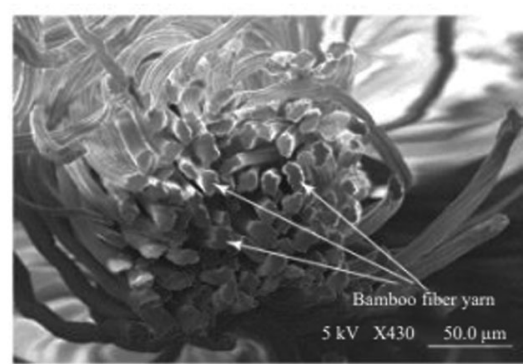

(b)

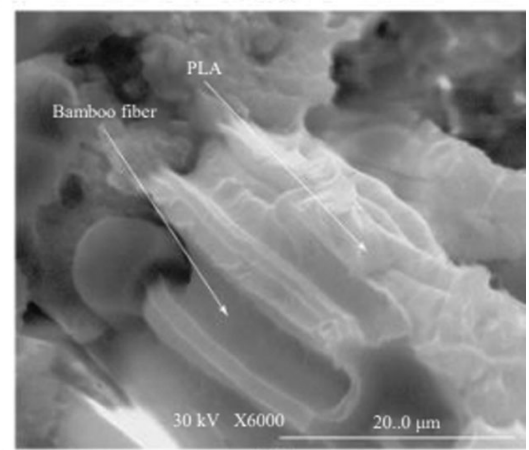

(d)

Figure 12: The SEM image of the bond between the bamboo fiber and polylactide matrix: (a) Fracture of fiber yarn at a different length, (b) Bamboo fiber yarn, (c) Fiber bundles are attached to each other by the matrix, (d) Adhesion between the bamboo fibers and the PLA matrix [109]

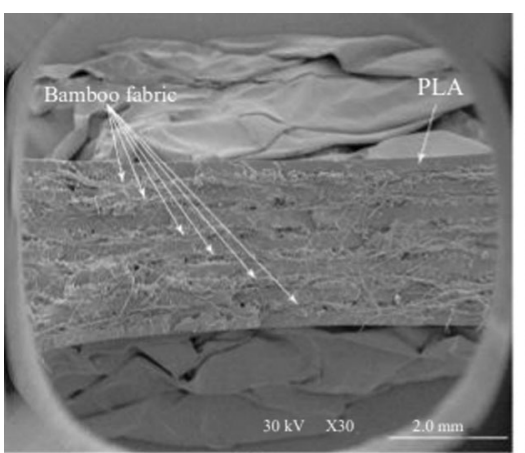

(a)

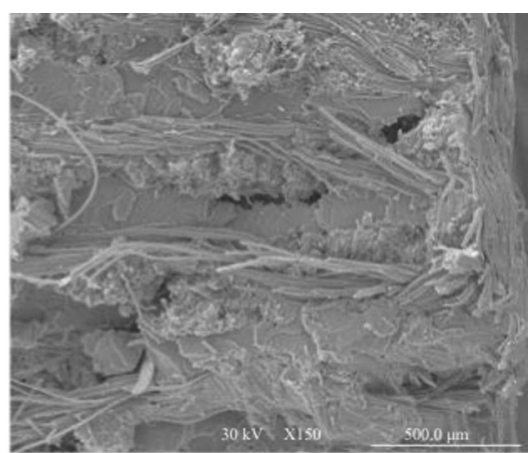

(b)

Figure 13: SEM image of the Bamboo fabric/PLA laminate tensile fracture: (a) Structure of laminate, (b) matrix cracking [109]

From the aforementioned detailed review, it is obvious that many researchers across the globe, especially in China where bamboo is in abundance, investigated microstructural and mechanical properties of various types of composites containing bamboo fiber. One of the primary focuses of previous research was to investigate the effect of using different proportions of bamboo fibers in composites and study the relevant changes in mechanical and physical performance. Whilst those investigations are useful, there should be more fundamental research to examine how bamboo fibers interact at the micro-level with other composite materials to achieve an optimum mix proportion. Considering bamboo is a natural fiber, the 
durability aspect of such hybrid composites must be carefully investigated for practical applications. The use of excessive bamboo fibers will most likely deteriorate mechanical performance as has been reported by some researchers. Systematic fundamental research would be required to explore the full potential of bamboo fibers' usage in engineering applications. Alkali treatment has been reported to have a positive effect on the mechanical properties of extracted fibers. Significant research is required on extraction techniques so that large-scale commercial production of bamboo fiber is possible, and the relevant treatment method should also be investigated to enhance their mechanical properties for engineering applications. Fire resistance of bamboo fiber based composites [110] should also be further investigated.

\section{Conclusion}

As a fast-growing natural renewable material, bamboo could offer excellent sustainable solutions to reducing the carbon footprint of the construction sector, especially in highly populated regions in the world where bamboo is available in abundance. Whilst the use of round bamboo in construction has been in practice for centuries, recent advancements in manufacturing technologies have seen innovation in engineered bamboo products as well as in the use of bamboo fiber for various applications. Bamboo fibers can be extracted directly from natural bamboo using a number of techniques although the existing production techniques for fiber extraction are relatively complicated. Typically, several steps are involved in producing bamboo fibers with excellent mechanical properties. The treatment method is also a key factor in retaining useful mechanical properties of the fiber; alkali treatment has been reported to outperform other methods. Tensile testing of single fiber and nanoindentation are two common methods used to measure the mechanical properties of bamboo fiber. Many factors have been reported to affect the mechanical properties of bamboo fibers, such as the chemical composition, bamboo fiber structure, moisture content, etc. Existing test evidence shows that bamboo fiber offers excellent mechanical properties; tensile properties are significantly superior to wood fibers and are comparable to some artificial fibers that are used in producing composite materials. Bamboo fibers have been used in many composites to investigate their effect on the overall performance of the composite materials and reported results are quite promising. However, more systematic and comprehensive investigations would be required to develop commercial-level business cases for bamboo fiber based composite production.

Funding Statement: The research work presented in this paper is supported by the National Natural Science Foundation of China (Nos. 51878354 and 51308301), the Natural Science Foundation of Jiangsu Province (Nos. BK20181402 and BK20130978), Six Talent Peak High-Level Projects of Jiangsu Province (No. JZ029), and Qinglan Project of Jiangsu Higher Education Institutions. Any research results expressed in this paper are those of the writers and do not necessarily reflect the views of the foundations.

Conflicts of Interest: The authors declare that they have no conflicts of interest to report regarding the present study.

\section{References}

1. van der Lugt, P., van den Dobbelsteen, A. A. J. F., Janssen, J. J. A. (2006). An environmental, economic and practical assessment of bamboo as a building material for supporting structures. Construction and Building Materials, 20(9), 648-656. DOI 10.1016/j.conbuildmat.2005.02.023.

2. Hong, C. K., Li, H. T., Lorenzo, R., Wu, G., Corbi, I. et al. (2019). Review on connections for original bamboo structures. Journal of Renewable Materials, 7(8), 713-730. DOI 10.32604/jrm.2019.07647.

3. Dauletbek, A., Li, H. T., Xiong, Z. H., Lorenzo, A. (2021). A review of mechanical behavior of structural laminated bamboo lumber. Sustainable Structures, 1(1), 000004.

4. Li, Y. J., Lou, Z. C. (2021). Progress of bamboo flatten technology research. Journal of Forestry Engineering, 6(4), 14-23. DOI 10.13360/j.issn.2096-1359.202012021. 
5. Su, J. W., Li, H. T., Xiong, Z. H., Lorenzo, A. (2021). Structural design and construction of an office building with laminated bamboo lumber. Sustainable Structures, 1(2), 000010.

6. Li, H. T., Xuan, Y. W., Xu, B., Li, S. H. (2020). Bamboo application in civil engineering field. Journal of Forestry Engineering, 5(6), 1-10. DOI 10.13360/j.issn.2096-1359.202003001.

7. Hong, C. K., Li, H. T., Xiong, Z. H., Lorenzo, R., Corbi, I. et al. (2020). Review of connections for engineered bamboo structures. Journal of Building Engineering, 30(1), 101324. DOI 10.1016/j.jobe.2020.101324.

8. Lou, Z. C., Yang, L. T., Zhang, A. W., Shen, D. H., Liu, J. et al. (2020). Influence of saturated steam heat treatment on the bamboo color. Journal of Forestry Engineering, 5(4), 38-44. DOI 10.13360/j.issn.20961359.201906044.

9. Wei, X., Chen, F. M., Wang, G. (2020). Flexibility characterization of bamboo slivers through winding-based bending stiffness method. Journal of Forestry Engineering, 5(2), 48-53. DOI 10.13360/j.issn.20961359.201905046.

10. Ramesh, M., Palanikumar, K., Reddy, K. H. (2017). Plant fibre based bio-composites: Sustainable and renewable green materials. Renewable and Sustainable Energy Reviews, 79(18), 558-584. DOI 10.1016/j.rser.2017.05.094.

11. Bousfield, G., Morin, S., Jacquet, N., Richel, A. (2018). Extraction and refinement of agricultural plant fibers for composites manufacturing. Comptes Rendus Chimie, 21(9), 897-906. DOI 10.1016/j.crci.2018.07.001.

12. Senthilkumar, K., Saba, N., Rajini, N., Chandrasekar, M., Jawaid, M. et al. (2018). Mechanical properties evaluation of sisal fibre reinforced polymer composites: A review. Construction and Building Materials, 174, 713-729. DOI 10.1016/j.conbuildmat.2018.04.143.

13. Xian, X. J., Xian, D. G. (1990). The relationship of microstructure and mechanical properties of bamboo. Journal of Bamboo Research, 9(3), 10-23.

14. Grosser, D., Liese, W. (1971). On the anatomy of Asia bamboos, with special reference to their vascular bundles. Wood Science and Technology, 5(4), 290-312. DOI 10.1007/BF00365061.

15. Mwaikambo, L. (2006). Review of the history, properties and application of plant fibres. African Journal of Science and Technology, 7(2), 121.

16. Dunne, R., Desai, D., Sadiku, R., Jayaramudu, J. (2016). A review of natural fibres, their sustainability and automotive applications. Journal of Reinforced Plastics and Composites, 35(13), 1041-1050. DOI 10.1177/ 0731684416633898.

17. Lou, Z. C., Yuan, C. L., Li, Y. J., Shen, D. H., Yang, L. T. et al. (2020). Effect of saturated steam treatment on the chemical composition and crystallinity properties of bamboo bundles. Journal of Forestry Engineering, 5(2), 2935. DOI 10.13360/j.issn.2096-1359.201905014.

18. Jia, H., Sheng, Y., Lv, H., Kim, Y. R., Zhao, X. et al. (2021). Effects of bamboo fiber on the mechanical properties of asphalt mixtures. Construction and Building Materials, 289(4), 123196. DOI 10.1016/j. conbuildmat.2021.123196.

19. Zhang, Y., Wang, C. H., Peng, J. X. (2014). Preparation and technology of bamboo fiber and its products. Beijing: China Textile Publishing House.

20. Sun, M., Zhu, X., Jiang, M. (2020). Exploring the innovation landscape of bamboo fiber technologies from global patent data perspective. Cellulose, 27, 9137-9156. DOI 10.1007/s10570-020-03431-z.

21. Chokshi, S., Parmar, V., Gohil, P., Chaudhary, V. (2020). Chemical composition and mechanical properties of natural fibers. Journal of Natural Fibers, 1-12. DOI 10.1080/15440478.2020.1848738.

22. Takahashi, Y., Matsunaga, H. (1991). Crystal structure of native cellulose. Macromolecules, 24(13), 3968-3969. DOI 10.1021/ma00013a035.

23. Gardner, K. H., Blackwell, J. (1974). The structure of native cellulose. Biopolymers, 13(10), 1975-2001. DOI 10.1002/bip.1974.360131005.

24. Wang, Y. P., Wang, G., Cheng, H. T., Tian, G. L., Liu, Z. (2010). Structures of bamboo fiber for textiles. Textile Research Journal, 80(4), 334-343. DOI 10.1177/0040517509337633.

25. Xu, W. (2006). Extraction of natural bamboo fiber and the research on its structure and chemical properties (Master Thesis). Suzhou, China: Soochow University. 
26. Fengel, D., Shao, D. (1984). A chemical and ultrastructural study of the bamboo species Phyllostachys makinoi Hay. Wood Science and Technology, 18(2), 103-112. DOI 10.1007/BF00350469.

27. Sun, S. N., Yuan, T. Q., Li, M. F., Cao, X. F., Liu, Q. Y. (2012). Structural characterization of hemicelluloses from bamboo culms (Neosinocalamus affinis). Cellulose Chemistry and Technology, 46(3-4), 165-176.

28. Osorio, L., Trujillo, E., van Vuure, A. W., Verpoest, I. (2011). Morphological aspects and mechanical properties of single bamboo fibres and flexural characterization of bamboo/epoxy composites. Journal of Reinforced Plastics and Composites, 30(5), 396-408. DOI 10.1177/0731684410397683.

29. Liese, W. (1998). The anatomy of bamboo culms. NBAR Technical Report No. 18. International Network for Bamboo and Rattan.

30. Xi, L. X., Qin, D. C. (2012). The antibacterial performance of natural bamboo fiber and its influencing factors. Proceedings of the 55th International Convention of Society of Wood Science and Technology, pp. 1-8. Beijing, China.

31. Afrin, T., Tsuzuki, T., Kanwar, R. K., Wang, X. (2012). The origin of the antibacterial property of bamboo. Journal of the Textile Institute, 103(8), 844-849. DOI 10.1080/00405000.2011.614742.

32. Zou, L., Jin, H., Lu, W. Y., Li, X. (2009). Nanoscale structural and mechanical characterization of the cell wall of bamboo fibers. Materials Science and Engineering C, 29(4), 1375-1379. DOI 10.1016/j.msec.2008.11.007.

33. Defoirdt, N., Biswas, S., Vriese, L. D., Tran, L. Q. N., Acker, J. V. et al. (2010). Assessment of the tensile properties of coir, bamboo and jute fibre. Composites Part A: Applied Science and Manufacturing, 41(5), 588-595. DOI 10.1016/j.compositesa.2010.01.005.

34. Chen, H., Yu, Y., Zhong, T., Wu, Y., Li, Y. et al. (2017). Effect of alkali treatment on microstructure and mechanical properties of individual bamboo fibers. Cellulose, 24(1), 333-347. DOI 10.1007/s10570-0161116-6.

35. Chin, S. C., Tee, K. F., Tong, F. S., Ong, H. R., Gimbun, J. (2020). Thermal and mechanical properties of bamboo fiber reinforced composites. Materials Today Communications, 23(3), 100876. DOI 10.1016/j.mtcomm.2019.100876.

36. Chen, H., Zhang, W., Wang, X., Wang, H., Wu, Y. et al. (2018). Effect of alkali treatment on wettability and thermal stability of individual bamboo fibers. Journal of Wood Science, 64(4), 398-405. DOI 10.1007/ s10086-018-1713-0.

37. Zhang, K., Wang, F., Liang, W., Wang, Z., Duan, Z. et al. (2018). Thermal and mechanical properties of bamboo fiber reinforced epoxy composites. Polymers, 10(6), 608. DOI 10.3390/polym10060608.

38. An, X., Liu, J., Liu, L., Zhang, H., Nie, S. et al. (2020). Improving the flexibility of bamboo mechanical pulp fibers for production of high soft tissue handsheets. Industrial Crops and Products, 150(6), 112410. DOI 10.1016/j.indcrop.2020.112410.

39. Mott, L., Shaler, S. M., Groom, L. H., Liang, B. H. (1995). Tensile testing of individual wood fibers using environmental scanning electron microscopy and video image analysis. Tappi Journal, 78(5), 143-148.

40. Yagi, S., Kobayashi, H. (2020). Fatigue and tensile properties of aramid fibers measured by single fiber mechanical tests. Journal of Macromolecular Science-Part B, 60(3), 220-236. DOI 10.1080/00222348.2020.1843856.

41. Tian, G. L. (2015). The main influence factors of bamboo fiber mechanical properties (Ph.D. Thesis). Beijing, China: China Academy of Forestry Sciences.

42. Li, Y., Huang, C., Wang, L., Wang, S., Wang, X. (2017). The effects of thermal treatment on the nanomechanical behavior of bamboo (Phyllostachys pubescens Mazel ex H. de Lehaie) cell walls observed by nanoindentation, XRD, and wet chemistry. Holzforschung, 71(2), 129-135. DOI 10.1515/hf-2016-0124.

43. Wimmer, R., Lucas, N. B., Tsui, T. Y., Oliver, W. C. (1997). Longitudinal hardness and Young's modulus of spruce trachied secondary walls using nanoindentation technique. Wood Science and Technology, 31(2), 131141. DOI 10.1007/BF00705928.

44. Faruk, O., Bledzki, A. K., Fink, H. P., Sain, M. (2012). Biocomposites reinforced with natural fibers: 2000-2010. Progress in Polymer Science, 37(11), 1552-1596. DOI 10.1016/j.progpolymsci.2012.04.003.

45. Tan, T., Rahbar, N., Allameh, S. M., Kwofie, S., Dissmore, D. et al. (2011). Mechanical properties of functionally graded hierarchical bamboo structures. Acta Biomaterialia, 7(10), 3796-3803. DOI 10.1016/j. actbio.2011.06.008. 
JRM, 2022, vol.10, no.3

46. Wang, G., Shi, S. Q., Wang, J. W., Yu, Y., Cao, H. P. et al. (2011). Tensile properties of four types of individual cellulosic fibers. Wood and Fiber Science, 43(4), 353-364.

47. Wang, X., Keplinger, T., Gierlinger, N., Burgert, I. (2014). Plant material features responsible for bamboo's excellent mechanical performance: A comparison of tensile properties of bamboo and spruce at the tissue, fibre and cell wall levels. Annals of Botany, 114(8), 1627-1635. DOI 10.1093/aob/mcu180.

48. Wang, X. Q., Ren, H. Q., Zhang, B., Fei, B. H., Ingo, B. (2012). Cell wall structure and formation of maturing fibres of moso bamboo (Phyllostachys pubescens) increase buckling resistance. Journal of the Royal Society, 9(70), 988-996. DOI 10.1098/rsif.2011.0462.

49. Rao, K. M. M., Rao, K. M. (2007). Extraction and tensile properties of natural fibers: Vakka, date and bamboo. Composite Structures, 77(3), 288-295. DOI 10.1016/j.compstruct.2005.07.023.

50. Wang, F. L., Shao, Z. P. (2020). Study on the variation law of bamboo fibers' tensile properties and the organization structure on the radial direction of bamboo stem. Industrial Crops and Products, 152(130), 112521. DOI 10.1016/j.indcrop.2020.112521.

51. Zhang, S. Y., Fei, B. H., Yu, Y., Cheng, H. T., Wang, C. G. (2013). Effect of the amount of lignin on tensile properties of single wood fibers. Forest Science and Practice, 15(1), 56-60. DOI 10.1007/s11632-013-0106-0.

52. Pramudi, G., Raharjo, W. W., Ariawan, D., Ubaidillah, A. Z. et al. (2021). Utilization of bamboo fiber in the development of environmentally friendly composite: A review. IOP Conference Series: Materials Science and Engineering, 1096(1), 012038. DOI 10.1088/1757-899X/1096/1/012038.

53. Wang, H., An, X., Li, W., Wang, H., Yu, Y. (2014). Variation of mechanical properties of single bamboo fibers (Dendrocalamus latiflorus Munro) with respect to age and location in culms. Holzforschung, 68(3), 291-297. DOI 10.1515/hf-2013-0081.

54. Page, D. H., El-Hosseiny, F. (1983). The mechanical properties of single wood pulp fibers. Part VI. Fibril angle and the shape of the stress-strain curve. Journal of Pulp and Paper Science, 9(4), 99-100.

55. Groom, L., Mott, L., Shaler, S. M. (2002). Mechanical properties of individual southern pine fibers. Part I: Determination and variability of stress-strain curves with respect to tree height and juvenility. Wood and Fiber Science, 34(1), 14-27.

56. Gindl, W., Gupta, H. S., Schöberl, T., Lichtenegger, H. C., Fratzl, P. (2004). Mechanical properties of spruce wood cell walls by nanoindentation. Applied Physics A, 79(8), 2069-2073. DOI 10.1007/s00339-004-2864-y.

57. Wang, H., Wang, H., Li, W., Ren, D., Yu, Y. (2013). Effects of moisture content on the mechanical properties of Moso Bamboo at the macroscopic and cellular levels. Bioresources, 8(4), 5475-5484. DOI 10.15376/ biores.8.4.5475-5484.

58. Hu, M., Wang, C., Lu, C., Anuar, N. I. S., Yousfani, S. H. S. et al. (2019). Investigation on the classified extraction of the bamboo fiber and its properties. Journal of Natural Fibers, 17, 1798-1808 DOI 10.1080/ 15440478.2019.1599311.

59. Li, H., Zhou, G. Y., Zhang, H. Y. (2010). Research and utilization status of natural bamboo fiber. Advanced Materials Research, 159, 236-241. DOI 10.4028/www.scientific.net/AMR.159.236.

60. Zhang, G. C. (1984). A brief talk on bamboo papermaking. Paper Science and Technology (Guangdong Papermaking), 3(2), 20-22.

61. Chen, Z., Zhang, H., He, Z., Zhang, L., Yue, X. (2019). Bamboo as an emerging resource for worldwide pulping and papermaking. BioResources, 14(1), 3-5. DOI 10.15376/biores.14.1.3-5.

62. Fasake, V., Dashora, K. (2018). An alternative or optional source of non-wood fiber material (weeds) for papermaking. International Congress on Plant Based Natural Products: Phytocosmetics, Phytotherapeutics and Phytonutraceutics, Udaipur, Rajasthan, India.

63. Ding, Y. L. (2019). The status quo and development prospects of bamboo pulp production in China. Land Greening, (11), 11-12.

64. Wang, R., Guo, Z., Cai, C., Zhang, J., Bian, F. et al. (2021). Practices and roles of bamboo industry development for alleviating poverty in China. Clean Technologies and Environmental Policy, 23, 1687-1699. DOI 10.1007/ s10098-021-02074-3. 
65. Ashraf, M., Hasan, M. J., Al-deen, S. (2021). Semi-rigid behaviour of stainless steel beam-to-column bolted connections. Sustainable Structures, 1(1), 000002.

66. Meng, C., Li, W., Cai, L., Shi, X., Jiang, C. (2020). Experimental research on durability of high-performance synthetic fibers reinforced concrete: Resistance to sulfate attack and freezing-thawing. Construction and Building Materials, 262(14), 120055. DOI 10.1016/j.conbuildmat.2020.120055.

67. Da Silva, E. J., Marques, M. L., Velasco, F. G., Junior, C. F., Luzardo, F. M. et al. (2017). A new treatment for coconut fibers to improve the properties of cement-based composites-combined effect of natural latex/pozzolanic materials. Sustainable Materials and Technologies, 12, 44-51. DOI 10.1016/j.susmat.2017.04.003.

68. Wei, J., Meyer, C. (2017). Degradation of natural fiber in ternary blended cement composites containing metakaolin and montmorillonite. Corrosion Science, 120, 42-60. DOI 10.1016/j.corsci.2016.12.004.

69. Danso, H. (2017). Properties of coconut, oil palm and bagasse fibres: As potential building materials. Procedia Engineering, 200, 1-9. DOI 10.1016/j.proeng.2017.07.002.

70. Kumarasamy, K., Shyamala, G., Gebreyowhanse, H., Kumarasamy (2020). Strength properties of bamboo fiber reinforced concrete. IOP Conference Series Materials Science and Engineering, 981, 032063. DOI 10.1088/ 1757-899X/981/3/032063.

71. Goh, L. D., Zulkornain, A. S. (2019). Influence of bamboo in concrete and beam applications. Journal of Physics Conference Series, 1349, 012127. DOI 10.1088/1742-6596/1349/1/012127.

72. Terai, M., Minami, K. (2012). Fracture behavior and mechanical properties of bamboo fiber reinforced concrete. Key Engineering Materials, 488-489, 214-217. DOI 10.4028/www.scientific.net/KEM.488-489.214.

73. Wahyuni, A. S., Supriani, F., Elhusna, Gunawan, A. (2014). The performance of concrete with rice husk ash, sea shell ash and bamboo fibre addition. Procedia Engineering, 95(2), 473-478. DOI 10.1016/j.proeng.2014.12.207.

74. Ramaswamy, H. S., Ahuja, B. M., Krishnamoorthy, S. (1983). Behavior of concrete reinforced with jute, coir and bamboo fibres. International Journal of Cement Composites and Lightweight Concrete, 5(1), 3-13. DOI 10.1016/ 0262-5075(83)90044-1.

75. Chin, S. C., Moh, J. N. S., Doh, S. I., Yahaya, F. M., Gimbun, J. (2019). Strengthening of reinforced concrete beams using bamboo fiber/epoxy composite plates in flexure. Key Engineering Materials, 821, 465-471. DOI 10.4028/www.scientific.net/KEM.821.465.

76. Tripura, D. D., Gupta, S., Debbarma, B., Deep, R. S. S. (2020). Flexural strength and failure trend of bamboo and coir reinforced cement stabilized rammed earth wallettes. Construction and Building Materials, 242, 117986. DOI 10.1016/j.conbuildmat.2019.117986.

77. Xie, X., Zhou, Z., Yan, Y. (2019). Flexural properties and impact behaviour analysis of bamboo cellulosic fibers filled cement based composites. Construction and Building Materials, 220, 403-414. DOI 10.1016/j. conbuildmat.2019.06.029.

78. Akinyemi, A. B., Omoniyi, E. T., Onuzulike, G. (2020). Effect of microwave assisted alkali pretreatment and other pretreatment methods on some properties of bamboo fibre reinforced cement composites. Construction and Building Materials, 245, 118405. DOI 10.1016/j.conbuildmat.2020.118405.

79. Sanchez-Echeverri, L. A., Ganjian, E., Medina-Perilla, J. A., Quintana, G. C., Sanchez-Toro, J. H. (2021). Mechanical refining combined with chemical treatment for the processing of bamboo fibres to produce efficient cement composites. Construction and Building Materials, 269, 121232. DOI 10.1016/j. conbuildmat.2020.121232.

80. Huang, Z., Sun, Y., Musso, F. (2018). Hygrothermal performance of natural bamboo fiber and bamboo charcoal as local construction infills in building envelope. Construction and Building Materials, 177, 342-357. DOI 10.1016/j.conbuildmat.2018.05.071.

81. Zhou, Y. H., Huang, Y. J., Sayed, U., Wang, Z. (2021). Research on dynamic characteristics test of wooden floor structure for gymnasium. Sustainable Structures, 1(1), 000005.

82. Khalil, H., Bhat, I., Jawaid, M., Zaidon, A., Hermawan, D. et al. (2012). Bamboo fibre reinforced biocomposites: A review. Materials and Design, 42(3), 353-368. DOI 10.1016/j.matdes.2012.06.015. 
83. Li, S. H., Zeng, Q. Y., Xiao, Y. L., Fu, S. Y., Zhou, B. L. (1995). Biomimicry of bamboo bast fiber with engineering composite materials. Materials Science and Engineering C-Biomimetic Materials Sensors and Systems, 3(2), 125-130. DOI 10.1016/0928-4931(95)00115-8.

84. Mandal, S., Alam, S. (2012). Dynamic mechanical analysis and morphological studies of glass/bamboo fiber reinforced unsaturated polyester resin-based hybrid composites. Journal of Applied Polymer Science, 125(S1), E382-E387. DOI 10.1002/app.36304.

85. Samal, S. K., Mohanty, S., Nayak, S. K. (2009). Polypropylene-bamboo/glass fiber hybrid composites: Fabrication and analysis of mechanical, morphological, thermal, and dynamic mechanical behavior. Journal of Reinforced Plastics and Composites, 28(22), 2729-2747. DOI 10.1177/0731684408093451.

86. Rao, H. R., Rajulu, A. V., Reddy, G. R., Reddy, K. H. (2010). Flexural and compressive properties of bamboo and glass fiber-reinforced epoxy hybrid composites. Journal of Reinforced Plastics and Composites, 29(10), 14461450. DOI 10.1177/0731684409105077.

87. Bai, T., Wang, D., Yan, J., Cheng, W., Cheng, H. et al. (2021). Wetting mechanism and interfacial bonding performance of bamboo fiber reinforced epoxy resin composites. Composites Science and Technology, 213, 108951. DOI 10.1016/j.compscitech.2021.108951.

88. Hughes, M., Hill, C. A. S., Hague, J. R. B. (2002). The fracture toughness of bast fibre reinforced polyester composites Part 1 Evaluation and analysis. Journal of Materials Science, 37(21), 4669-4676. DOI 10.1023/ A:1020621020862.

89. Qiu, R., Liu, W., Wu, Y., Li, K. (2019). Development of a reinforced styrene-free unsaturated polyester composite based on bamboo fibers. Holzforschung, 73(7), 689-694. DOI 10.1515/hf-2018-0160.

90. Khan, Z., Yousif, B. F., Islam, M. (2017). Fracture behaviour of bamboo fiber reinforced epoxy composites. Composites Part B: Engineering, 116(3), 186-199. DOI 10.1016/j.compositesb.2017.02.015.

91. Nguyen, D. M., Grillet, A. C., Diep, T., Bui, Q. B., Woloszyn, M. (2018). Influence of thermo-pressing conditions on insulation materials from bamboo fibers and proteins based bone glue. Industrial Crops and Products, 111, 834-845. DOI 10.1016/j.indcrop.2017.12.009.

92. Kumari, S., Kumar, R., Rai, B., Kumar, G. (2020). Development of euphorbia latex and bamboo fiber based green composite. Journal of Nanoscience and Nanotechnology, 20(8), 5282-5287. DOI 10.1166/jnn.2020.18534.

93. Chen, X., Guo, Q., Mi, Y. (1998). Bamboo fiber-reinforced polypropylene composites: A study of the mechanical properties. Journal of Applied Polymer Science, 69(10), 1891-1899. DOI 10.1002/(SICI)1097-4628(19980906) 69:10<1891::AID-APP1>3.0.CO;2-9.

94. Phuong, N. T., Sollogoub, C., Guinault, A. (2010). Relationship between fiber chemical treatment and properties of recycled pp/bamboo fiber composites. Journal of Reinforced Plastics and Composites, 29(21), 3244-3256. DOI 10.1177/0731684410370905.

95. Lee, S. Y., Chun, S. J., Doh, G. H., Kang, I. A., Lee, S. et al. (2009). Influence of chemical modification and filler loading on fundamental properties of bamboo fibers reinforced polypropylene composites. Journal of Composite Materials, 43(15), 1639-1657. DOI 10.1177/0021998309339352.

96. Tang, Q. H., Wang, Y. F., Wang, G., Cheng, H. T., Guo, W. J. (2019). An Investigation on the comprehensive property assessment and future directions of single bamboo fiber reinforced polypropylene composites fabricated by a non-woven paving and advanced molding process. Materials, 12(16), 2641. DOI 10.3390/ ma12162641.

97. Lokesh, P., Kumari, T. S. A. S., Gopi, R., Loganathan, G. B. (2020). A study on mechanical properties of bamboo fiber reinforced polymer composite. Materials Today: Proceedings, 22, 897-903. DOI 10.1016/j. matpr.2019.11.100.

98. Nirmal, U., Hashim, J., Low, K. O. (2011). Adhesive wear and frictional performance of bamboo fibres reinforced epoxy composite. Tribology International, 47, 122-133. DOI 10.1016/j.triboint.2011.10.012.

99. Kushwaha, P. K., Kumar, R. (2010). Studies on water absorption of bamboo-epoxy composites: Effect of silane treatment of mercerized bamboo. Journal of Applied Polymer Science, 115(3), 1846-1852. DOI 10.1002/ app.31317. 
100. Huang, J. K., Young, W. B. (2019). The mechanical, hygral, and interfacial strength of continuous bamboo fiber reinforced epoxy composites. Composites Part B: Engineering, 166(2), 272-283. DOI 10.1016/j. compositesb.2018.12.013.

101. Chiu, H. H., Young, W. B. (2020). The longitudinal and transverse tensile properties of unidirectional and bidirectional bamboo fiber reinforced composites. Fibers and Polymers, 21(12), 2938-2948. DOI 10.1007/ s12221-020-0109-0.

102. Rajulu, V. A., Chary, N. K., Reddy, R. G., Meng, Y. Z. (2004). Void content, density and weight reduction studies on short bamboo fiber-epoxy composites. Journal of Reinforced Plastics and Composites, 23(2), 127-130. DOI $10.1177 / 0731684404029326$.

103. Tang, Q., Fang, L., Guo, W. (2019). Effects of bamboo fiber length and loading on mechanical, thermal and pulverization properties of phenolic foam composites. Journal of Bioresources and Bioproducts, 4(1), 51-59. DOI $10.21967 / j b b . v 4 i 1.184$.

104. Das, M., Chakraborty, D. (2007). Role of mercerization of the bamboo strips on the impact properties and morphology of unidirectional bamboo strips-novolac composites. Polymer Composites, 28(1), 57-60. DOI $10.1002 / \mathrm{pc} .20292$.

105. Yusof, F. M., Wahab, N. A., Rahman, N. L. A., Kalam, A., Jumahat, A. et al. (2019). Properties of treated bamboo fiber reinforced tapioca starch biodegradable composite. Materials Today: Proceedings, 16, 2367-2373. DOI 10.1016/j.matpr.2019.06.140.

106. Jena, P. C. (2018). Free vibration analysis of short bamboo fiber based polymer composite beam structure. Materials Today: Proceedings, 5(2), 5870-5875. DOI 10.1016/j.matpr.2017.12.185.

107. Rawi, N. F. M., Jayaraman, K., Bhattacharyya, D. (2013). A performance study on composites made from bamboo fabric and poly (lactic acid). Journal of Reinforced Plastics and Composites, 32(20), 1513-1525. DOI 10.1177/0731684413498296.

108. Nurul Fazita, M. R., Jayaraman, K., Bhattacharyya, D., Mohamad Haafiz, M. K., Saurabh, C. K. et al. (2016). Green composites made of bamboo fabric and poly (lactic) acid for packaging applications: A review. Materials, 9(6), 435. DOI 10.3390/ma9060435.

109. Porras, A., Maranon, A. (2012). Development and characterization of a laminate composite material from polylactic acid (PLA) and woven bamboo fabric. Composites Part B: Engineering, 43(7), 2782-2788. DOI 10.1016/j.compositesb.2012.04.039.

110. Kumari, S., Kumar, R., Rai, B., Kumar, G. (2021). Effect of euphorbia coagulum content on fire retardant and mechanical properties of polyester bamboo fiber composite. Fibers and Polymers, 22(3), 786-792. DOI 10.1007/s12221-021-0376-4. 